\title{
Implementation of preventive interventions - what are the contextual co-players and opponents?
}

Poulsen, Signe

Publication date:

2017

Document Version

Peer reviewed version

Link back to DTU Orbit

Citation (APA):

Poulsen, S. (2017). Implementation of preventive interventions - what are the contextual co-players and opponents?. Abstract from 12th International Conference on Occupational Stress and Health, Minneapolis, Minnesota, United States.

\section{General rights}

Copyright and moral rights for the publications made accessible in the public portal are retained by the authors and/or other copyright owners and it is a condition of accessing publications that users recognise and abide by the legal requirements associated with these rights.

- Users may download and print one copy of any publication from the public portal for the purpose of private study or research.

- You may not further distribute the material or use it for any profit-making activity or commercial gain

- You may freely distribute the URL identifying the publication in the public portal

If you believe that this document breaches copyright please contact us providing details, and we will remove access to the work immediately and investigate your claim 
WSH abstract (600-800 words)

Implementation of preventive interventions - what are the contextual co-players and opponents?

\section{Statement of the problem}

Preventive interventions aims at improving the psychosocial work environment within organizations. The nature of preventive interventions are therefore that it affects the context in which it is implemented. We will claim that the context also affects the implementation of the intervention.

When the context affects the intervention the current approach is to consider to which extent the intervention program was followed (implementation fidelity, (Carroll et al., 2007)). Implementation fidelity implies two underlying logics, one that intervention models always are applicable, and two that the model is implemented in a static organization (Gish, Poulsen, \& Ipsen, 2014; K. Nielsen, 2013). Implementation fidelity does not explain which organizational and managerial circumstances that affected the intervention positively or negatively. Thus, we find studies that show intervention models work, but the studies cannot explain why the intervention models work. Realistic evaluation has been suggested as an approach to gain information about which circumstances have affected who, and under which conditions (Hasle, Kvorning, Rasmussen, Smith, \& Flyvholm, 2012; K. Nielsen, Abildgaard, \& Daniels, 2014; Starheim, 2014).

When investigating the effects of interventions, it remains unclear which conditions have influenced the implementation process. The initial conditions suggested as important for the implementation process is among others management support (Cox et al., 2000; Kompier, Geurts, Grundemann, Vink, \& Smulders, 1998). Others have also pointed to the importance of employee involvement (Lamontagne, Keegel, Louie, Ostry, \& Landsbergis, 2007; Karina Nielsen, Randall, Holten, \& Gonzalez, 2010). However, the studies do not explain the causal relation behind. Qualitative studies find that the term management support is too broad a term, because support from both top management and the first line manager is crucial for the implementation process (Ipsen, Gish, \& Poulsen, 2014; K. Nielsen, 2013).

The general recommendation about employee involvement in interventions is criticized because it is not specified whether the involvement should be of all employees during the entire process, or it should just be involvement of few employees in one intervention step. (K. Nielsen, 2013).

Generally, we know much about the criteria for initiating an intervention, but we need more knowledge about how implementation actually happens. This paper investigates the promoting and inhibiting factors when implementing a preventive intervention.

The majority of studies investigating promoting and inhibiting factors in relation to implementation success primarily focus on the promoting factors. Inhibiting factors are lack of time for the intervention, change history in the organization, and that the intervention goals are not linked to the company's KPIs (Ipsen et al., 2014). Some of the promoting factors will inevitably be inhibiting when they are absent, but we do not know how lack of management support manifest itself.

\section{Procedures}

In Denmark the worksites within hospitals is managed by five regions. The Capital Region of Denmark employs 36000 people, who primarily work within healthcare. The worksites are primarily hospitals, but there are also residential accommodation and pharmacies. 
All capital worksites fill out an employee satisfaction survey every third year. When the results from the survey is announced, the worksites should identify target areas and hereafter initiatives to the target areas. We have identified the worksites where there has been a positive development in the psychosocial work environment from the employee satisfaction survey in 2011 to the survey in 2014.

We choose four worksites, where we do interviews with the managers and facilitate a chronicle workshop (Limborg \& Hvenegaard, 2011; Poulsen, Ipsen, \& Gish, 2014) with employees. The interviews seeks to investigate which initiatives was launched as a reaction to the employee satisfaction survey in 2011 , and the chronicle workshop investigates whether the initiatives was actually implemented in the daily work routines, and whether other circumstances could have influenced the employee satisfaction survey in 2014.

\section{Analysis}

Datacollection is currently ongoing.

The interviews and the chronicle workshop will be transcribed before the data is analyzed. The analysis will initially consider promoting and inhibiting factors in relation to implementation of initiatives at the worksites. The initial analysis will guide the in-depth analysis afterwards.

\section{Results}

Results are not available yet.

\section{Practical Implications}

We intend to develop an implementation tool, which supports managers and employees in the implementation process.

\section{Conclusion}

Conclusion is not available yet.

Carroll, C., Patterson, M., Wood, S., Booth, A., Rick, J., \& Balain, S. (2007). A conceptual framework for implementation fidelity. Implementation Science : IS, 2, 40. http://doi.org/10.1186/1748-5908-2-40

Cox, T., Griffiths, A., Barlowe, C., Randall, R., Thomson, L., \& Rial-gonzalez, E. (2000). Organisational interventions for work stress - A risk management approach.

Gish, L., Poulsen, S., \& Ipsen, C. (2014). Design for Fidelity - Inscription of Intended Actions, Participation and Behavior in Intervention Frameworks. In O. Broberg, N. Fallentin, P. Hasle, P. L. Jensen, A. Kabel, M. Larsen, \& T. Weller (Eds.), Human Factors in Organizational Design and Management - XI (pp. 737738). IEA Press.

Hasle, P., Kvorning, L. V, Rasmussen, C. D., Smith, L. H., \& Flyvholm, M.-A. (2012). A Model for Design of Tailored Working Environment Intervention Programmes for Small Enterprises. Safety and Health at Work, 3, 181. http://doi.org/10.5491/SHAW.2012.3.3.181

Ipsen, C., Gish, L., \& Poulsen, S. (2014). Organizational-level interventions in small and medium-sized enterprises: Enabling and inhibiting factors in the PoWRS program. Safety Science. http://doi.org/10.1016/j.ssci.2014.07.017

Kompier, M. A. J., Geurts, S. A. E., Grundemann, R. W. M., Vink, P., \& Smulders, P. G. W. (1998). Cases in Stress Prevention: The Success of a Participative and Stepwise Approach. Stress Medicine, 14(3), 155168. JOUR.

Lamontagne, A. D., Keegel, T., Louie, A. M., Ostry, A., \& Landsbergis, P. A. (2007). A systematic review of the job-stress intervention evaluation literature, 1990-2005. International Journal of Occupational and Environment Health, 13(1), 268-280. JOUR.

Limborg, H. J., \& Hvenegaard, H. (2011). The Chronicle Workshop - The use of narratives to reveal the story 
of a work community and understand its culture. In Facilitating Change - Using interactive methods in organizations, communities and networks (pp. 305-325).

Nielsen, K. (2013). Review Article: How can we make organizational interventions work? Employees and line managers as actively crafting interventions. Human Relations, 66(8), 1029-1050. http://doi.org/10.1177/0018726713477164

Nielsen, K., Randall, R., Holten, A.-L., \& Gonzalez, E. R. (2010). Conducting organizational-level occupational health interventions: What works? Work and Stress, 24(3), 234-259. JOUR.

Nielsen, K., Abildgaard, J. S., \& Daniels, K. (2014). Putting context into organizational intervention design: Using tailored questionnaires to measure initiatives for worker well-being. Human Relations, 67(12), 1537-1560. http://doi.org/10.1177/0018726714525974

Poulsen, S., Ipsen, C., \& Gish, L. (2014). The use of the Chronicle Workshop as a method for evaluating participatory interventions. 11th International Symposium on Human Factors in Organisational Design and Management And 46th Annual Nordic Ergonomics Society Conference, 3, 725-730.

Starheim, L. (2014). Realistic evaluation of interventions in the psycho social working environment. In 0. Broberg, N. Fallentin, P. Hasle, P. L. Jensen, A. Kabel, M. E. Larsen, \& T. Weller (Eds.), Human Factors in Organizational Design and Management - XI. (pp. 581-582). IEA Press.

Summary (3-4 sentences):

Preventive interventions aims at improving the psychosocial work environment within organizations. When investigating the effects of interventions, it remains unclear which conditions have influenced the implementation process, and which effect the conditions had on the implementation process. We investigate the contextual factors in an implementation process related to an employee satisfaction survey, and investigate whether the factors have been inhibiting ir promoting for the process.

Learning objectives (2-6):

After attending the presentation you should be able to:

- Identify contextual factors that affects an implementation process

- Describe how how contextial factors affect implementation processes

Themes or questions adressed in presentation:

The presentation addresses the contextual factors in an implementation process, and whether they promote or inhibit the process. 